\title{
AKIBAT HUKUM TERHADAP EKSEKUSI LELANG DENGAN TANPA ADANYA PUTUSAN PENGADILAN (Studi di Pengadilan Agama Semarang)
}

\author{
A Hashfi Luthfi*, Ro'fah Setyowati**, Siti Malikatun Badriyah**** \\ Program Studi Magister Ilmu Hukum \\ Fakultas Hukum Universitas Diponegoro
}

\begin{abstract}
ABSTRAK
Dalam penulisan ini membahas mengenai masalah eksekusi lelang pada sengketa ekonomi syariah di Pengadilan Agama Semarang. Penulisan hukum ini berusaha untuk mengetahui tentang bagaimana pelaksanaan eksekusi lelang hak tanggungan pada sengketa ekonomi syariah, hambatan apa saja yang dihadapi oleh Pengadilan Agama Semarang dan bagaimana penanggulangan terhadap hambatan-hambatan tersebut. Berdasarkan hasil penelitian, penulis memperoleh jawaban atas permasalahn yang ada bahwa eksekusi lelang pada sengketa ekonomi syariah dengan tanpa adanya putusan pengadilan dapat dilakukan parate eksekusi melalui balai lelang swasta atau dapat eksekusi berdasarkan title eksekutorial dengan mengajukan permohonan kepada Pengadilan Agama. Eksekusi lelang melalui pelelangan umum cenderung lebih mudah dan tidak memakan banyak biaya daripada eksekusi dengan pertolongan hakim karena tidak memerlukan adanya perintah dari Ketua Pengadilan. Akan tetapi dalam hal adanya perlawanan debitor balai lelang swasta ataupun KPKNL tidak memiliki kewenangan untuk melakukan eksekusi pengosongan atas objek lelang yang sudah dibeli oleh peserta lelang. Hal tersebut terjadi karena Pengadilan menganggap bahwa terhadap Objek Lelang yang dijual oleh Balai Lelang Swasta tidak terdapat peletakkan sita (beslag) oleh badan Peradilan. Sementara prosedur hukum untuk melakukan eksekusi pengosongan mewajibkan harus adanya penetapan sita terlebih dahulu oleh Pengadilan. Hambatan yang dihadapi Pengadilan Agama Semarang dalam pelaksanaan eksekusi lelang Hak Tanggungan adalah karna adanya perlawanan dari pihak tereksekusi yang mencoba menghalangi proses lelang dengan cara premanisme dan adanya perlawanan dari pihak ketiga.
\end{abstract}

\section{Kata kunci : Ekonomi Syariah; Eksekusi Lelang; Pengadilan Agama}

* Mahasiswa Program Studi Magister IImu Hukum UNDIP

** Penulis Kedua, Penulis Koresponden

*** Penulis Ketiga 


\section{Pendahuluan}

\section{A. Latar Belakang}

Tujuan pihak-pihak yang berperkara menyerahkan perkara-perkaranya kepada pengadilan tidak sebatas untuk menyelesaikan perkara mereka secara tuntas dengan adanya putusan pengadilan. Namun tujuan akhir mereka adalah agar segala hak-haknya yang dirugikan oleh pihak lain dapat dipulihkan melalui putusan pengadilan/hakim. Dan pemulihan tersebut akan tercapai apabila putusan dapat dilaksanakan/dapat dieksekusi.

Persoalan eksekusi ini semakin penting untuk dikaji mengingat ekonomi syariah yang menarik semakin banyak orang menggelutinya. Alhasil, potensi sengketanya pun makin besar. Ekonomi syariah adalah kegiatan usaha yang dilaksanakan berdasarkan prinsip-prinsip syariah. Kini sudah ada bank syariah, reasuransi syariah, reksadana syariah, obligasi syariah, sekuritas syariah, pembiayaan syariah, pegadaian syariah dan lain-lain. Jenis-jenis bisnis syariah ini sudah diakomodasi dalam UU No. 3 Tahun 2006 tentang Perubahan atas UU No. 7 Tahun 1989 tentang Peradilan Agama. Terakhir diubah dengan UU No. 50 Tahun 2009.

Eksekusi lelang pada Pengadilan Agama tidak selalu berdasarkan putusan dari pengadilan, akan tetapi juga dapat dilakukan berdasarkan ketentuan lelang eksekusi yang terdapat pada Pasal 6 Undang-undang nomor 4 tahun 1996 Tentang Hak Tanggungan Atas Tanah Beserta Benda-benda yang Berkaitan dengan Tanah, untuk mudahnya disebut UUHT. Dalam hal ini Pengadilan Agama Semarang berdasarkan data yang terdapat di Direktorat Pranata dan Tatalaksana Perkara Perdata Agama menjadi satu-satunya Pengadilan Agama di wilayah Jawa Tengah yang menerima eksekusi lelang tanpa adanya putusan Pengadilan. Mekanisme permohonan eksekusi lelang hak tanggungan pada pengadilan agama masih menggunakan hukum acara yang berlaku di peradilan umum. Pertama, argumentasi itu didasarkan pada Pasal 54 UU Peradilan Agama yang tegas-tegas menyatakan hukum acara yang berlaku di peradilan umum dipakai di lingkungan peradilan kecuali yang secara khusus telah diatur dalam UU Peradilan Agama. Kedua, sebagian besar payung hukum eksekusi lelang hak tanggungan memang masih berpatokan pada hukum yang dipakai di peradilan umum. Seperti UU No. 4 Tahun 1996 tentang Hak Tanggungan.

Adanya pelaksanaan eksekusi Hak Tanggungan, adalah karena adanya kewajiban dari debitor kepada kreditor yang tidak terpenuhi, dimana sebelumnya telah dibuat suatu perjanjian antara debitor dan kreditor dengan ditanda tanganinya Akta Pemberian Hak 
Jurnal Law Reform

Volume 12, Nomor 2, Tahun 2016

Tanggungan yang dibuat di hadapan Pejabat Pembuat Akta Tanah (PPAT), dan didaftarkan di Kantor Pertanahan. ${ }^{1}$ Suatu keadaan dimana debitor tidak melaksanakan prestasinya sesuai dengan apa yang telah dijanjikannya, karena kesalahannya dan ia telah ditegur, maka pelaksanaan eksekusi dapat dilakukan.

Khusus mengenai eksekusi dengan pertolongan hakim yang menjadikan Pasal 224 HIR / 258 RBg sebagai dasarnya, dibutuhkan keterlibatan dan peran dari Pengadilan dimana debitor diam atau tinggal, dalam hal ini wewenang Ketua Pengadilan setempat.

Peneliti melakukan pra riset pada Pengadilan Agama semarang dan mendapatkan keterangan dari pihak Pengadilan bahwa eksekusi penetapan Pengadilan terhadap objek jaminan Hak Tanggungan sering menimbulkan keberatan atau perlawanan atas penyitaan yang diletakkan terhadap objek jaminan, perlawanan eksekusi ini disebabkan debitor merasa dirugikan dengan adanya eksekusi tersebut. Perlawanan yang dilakukan oleh dibitor bertujuan untuk menggagalkan pelaksanaan eksekusi oleh Pengadilan Agama sehingga dalam prakteknya Pengadilan Agama mendapatkan hambatan dari pihak kreditor. ${ }^{2}$

1 Lihat Pasal 11 ayat (2) UU No. 4 Tahun 1996 tentang Hak Tanggungan.

2 Wawancara dengan $H$. Abdul Wahid, S.H., M.Hum., selaku Panitera Pengadilan Agama Semarang pada pukul. 10.00 WIB tanggal 6 Desember 2016.
Program Studi Magister Ilmu Hukum Fakultas Hukum Universitas Diponegoro

Pelaksanaan terhadap eksekusi lelang Hak Tanggungan di Pengadilan Agama Semarang masih tergolong baru, berdasarkan data yang diperoleh penulis dari Dirjen Badilag MA RI bahwa Pengadilan Agama Semarang menjadi satu-satunya Pengadilan Agama yang telah menerima permohonan eksekusi lelang Hak Tanggungan di wilayah Jawa Tengah sejak kewenangan tersebut di berikan pada Lembaga Peradilan Agama. $^{3}$ Pengadilan Agama Semarang sendiri baru satu kali menerima permohonan eksekusi lelang hak tanggungan yang diajukan oleh Bank Permata Unit Syariah. Permohonan eksekusi lelang tersebut diajukan sejak tahun 2013 dan sampai saat ini pada 2017 pelaksanaan lelang eksekusi oleh Pengadilan Agama masih mengalami kendala. ${ }^{4}$

\section{B. Permasalahan}

Berdasarkan pada permasalahanpermasalahan tersebut, peneliti ingin melakukan penelitian dan kajian mengenai "Akibat Hukum terhadap eksekusi lelang pada sengketa ekonomi syariah dengan tanpa adanya putusan Pengadilan (Studi Pada Pengadilan Agama Semarang)". Atas dasar pokok pikiran yang

3 DIRJEN BADILAG MARI, "Laporan Tentang Perkara yang Diterima dan Diputus - L1PA.8 Data Total Secara Nasional Desember 2015" dalam http://infoperkara.badilag.net/ . Diakses pada 21 November 2016.

4 Wawancara dengan H. Zainal Abidin, S.Ag., selaku Wakil Panitera Pengadilan Agama Semarang pada pukul 09.30 WIB tanggal 17 Januari 2017. 
melatarbelakangi penelitian ini serta asumsiasumsi yang telah disebutkan diatas, maka untuk mempertajam penelaahan dan analisis, diajukan permasalahan yang mencakup hal-hal sebagai berikut:

1. Bagaimanakah cakupan eksekusi lelang pada sengketa ekonomi syariah dengan tanpa adanya putusan pengadilan?

2. Bagaimanakah hambatan yang dialami Pengadilan Agama Semarang dalam pelaksanaan eksekusi lelang dengan tanpa adanya putusan?

\section{Metode Penelitian}

\section{A. Jenis Penelitian}

Jenis penelitian yang digunakan dalam penulisan ini adalah penelitian yuridis empiris karena lebih sesuai dengan fokus bahasan dalam pembuatan tesis ini. Penelitian yuridis empiris dilakukan dengan cara meneliti di lapangan yang kemudian hasinya menjadi data primer, dan didukung dengan bahan-bahan pustaka yang merupakan data sekunder. 5 Hukum tidak lagi dikonsepkan secara filosofis moralistis sebagai ius constituendum (law as what ought to be), dan tidak pula secara positivistis sebagai ius constitutum (law what it is in the book), melainkan secara empiris sebagai ius operatum (law as what it is in society). ${ }^{6}$

B. Jenis Data

Sementara kategori data terbagi menjadi dua, yakni data primer dan data sekunder.

\section{Data Primer}

Data primer merupakan data yang diperoleh langsung dari sumber pertama, dalam hal ini data primer diperoleh penulis langsung dari penelitian lapangan melalui wawancara dengan narasumber terkait, dalam hal ini kepada kepanitraan dan hakim yang memiliki kompetensi dalam menangani sengketa ekonomi syariah di lingkungan Pengadilan Agama Semarang, petugas lelang dan lawyer pada KPKNL Semarang, dan tim Advokat pada SAP Law Office Sunarto - Agung Pribadi \& Partners, Adokat, Kurator dan Pengurus. Wawancara merupakan situasi peran antar pribadi bertatap-muka, proses tanya jawab secara lisan antara pihak penanya atau pencari informasi dengan pihak informan atau pemberi informasi sebagai narasumber menggunakan daftar pertanyaan sebagai pedoman, dengan maksud untuk memperoleh penjelasan dari informan.

\footnotetext{
${ }^{5}$ Ronny Haditijo Soemitro, Metodologi Penelitian Hukum, (Jakarta: Ghalia Indonesia, 2005), hlm. 15.
}

6 Bambang Sunggono, Metodologi Penelitian Hukum, (Jakarta: PT RajaGrafindo, 2005), hlm. 73. 


\section{Data Sekunder}

Sumber data sekunder merupakan data yang diperoleh melalui bahan-bahan kepustakaan atau studi dokumentasi dari bahan-bahan seperti Undang-Undang, literature, buku-buku lain yang berhubungan dengan penelitian ini yang terdiri dari bahan hukum primer, bahan hukum sekunder, dan bahan hukum tersier.

C. Spesifikasi Penelitian

Penelitian ini bersifat deskriptif analitis. Deskriptif yaitu menganalisa dan menyajikan fakta secara sistematis sehingga dapat lebih mudah untuk dipahami dan disimpulkan. Penelitian deskriptif ini menggunakan metode survei lapangan. ${ }^{7}$ Sedangkan analitis dilakukan dengan adanya suatu analisa terhadap permasalahan yang telah dikemukakan di muka dengan menggunakan peraturan PerundangUndangan yang berlaku, pendapat para ahli, dan teori-teori ilmu hukum yang berkaitan dengan eksekusi lelang tanpa adanya putusan dari pengadilan. Dengan demikian, penelitian ini dapat memberikan gambaran secara rinci, menyeluruh, dan sistematis mengenai kenyataan yang terjadi, yaitu mengenai akibat hukum eksekusi lelang pada sengketa ekonomi syariah tanpa adanya putusan di pengadilan agama semarang.

\section{Metode Analisis Data}

Setelah data primer dan data sekunder telah terkumpul, langkah selanjutnya akan dikelompokan secara sistematis dan disesuaikan dengan permasalahan yang diambil. Data yang telah terkumpul dan dikelompokan dianalisis dengan menggunakan metode analisa kualitatif (qualitative data analysis). Metode analisa kualitatif ini merupakan metode untuk menghasilkan data deskriptif, yaitu analisis terhadap data-data yang dinyatakan oleh responden secara tertulis atau lisan serta tingkah laku yang nyata, dan menganalisa bahan-bahan hukum. ${ }^{8}$ Analisis data kualitatif adalah suatu metode analisis data yang tidak berdasarkan angka-angka tetapi data yang telah didapat dirangkai dengan kata-kata dan kalimat. Dengan menggunakan metode kualitatif, penulis bertujuan untuk memahami atau mengerti gejala yang ditelitinya.

\section{Pembahasan}
A. Cakupan eksekusi lelang pada sengketa ekonomi syariah dengan tanpa adanya Putusan Pengadilan

7 Altherton \& Klemmack (Irawan Soehartono), Metode Penelitian Sosial - Suatu Tehnik Penelitian Bidang Kesejahteraan Sosial Lainnya, (Bandung: Remaja Rosda Karya, 1999), hlm. 63.
8 Mukti Fajar ND dan Yulianto Achmad. Dualisme Penelitian Hukum Normatif dan Empiris. (Yogyakarta: Pustaka Pelajar, 2010). hlm. 192. 
Jurnal Law Reform

Volume 12, Nomor 2, Tahun 2016

1.Eksekusi lelang berdasarkan title eksekutorial di Pengadilan Agama Semarang

Pengadilan Agama dalam melakanakan eksekusi Hak Tanggungan pada dasarnya telah diatur dalam Pasal 224 HIR/258 RBg, dalam hal menjalankanya jika tidak dilaksanakan secara sukarela maka pelaksanaanya dijalankan atas perintah dan di bawah pimpinan ketua pengadilan Agama di dalam wilayah mana debitor tinggal.

Dari hasil wawancara yang telah penulis lakukan di Pengadilan Agama Semarang, penulis memperoleh keterangan dari Bapak Abdul Wahid selaku panietra Pengadilan Agama Semarang tentang prosedur pelaksanaan eksekusi lelang hak tanggungan dengan tahapan sebagai berikut $: 9$

- Adanya permohonan dari kreditor kepada Ketua Pengadilan Agama Semarang

- Permohonan tersebut dilampiri dengan sertifikat Hak Tanggungan, perjanjian kredit, foto copy KTP debitor yang dilampirkan sebagai bukti tempat tinggal untuk pemanggilan.

- Ketua Pengadilan Agama mengeluarkan penetapan somasi guna memanggil

9 Wawancara dengan H. Abdul Wahid, S.H., M.Hum., selaku Panitera Pengadilan Agama Semarang pada pukul. 10.00 WIB tanggal 9 Februari 2017.
Program Studi Magister Ilmu Hukum Fakultas Hukum Universitas Diponegoro

debitor, jika debitor tidak hadir maka dibuatkan berita acara pemberian teguran.

- Kreditor mengajukan permohonan aanmaning serta mengajukan permohonan sita eksekusi atas obyek yang dijadikan jaminan kepada Ketua Pengadilan Agama dimana debitor tinggal.

- Selanjutnya kreditor mengajukan permohonan lelang eksekusi atau penjualan dimuka umum kepada Ketua Pengadilan Agama dengan disertakan perincian hutang debitur terhitung sejak tunggakan sampai diajukan eksekusi.

- Ketua Pengadilan mengeluarkan penetapan yang isinya perintah kepada Panitera atau Jurusita agar dengan perantaraan Kantor Lelang Negara melaksanakan penjualan umum (lelang eksekusi) atas objek hak tanggungan. Perintah Eksekusi dibuat dalam bentuk Penetapan tertulis. Dalam penetapan perintah eksekusi lelang tersebut dicantumkan bahwa hasil bersih dari penjualan lelang diserahkan kepada Panitera.

- Pelaksanaan lelang

- Permohonan lelang oleh Panitera Pengadilan Agama kepada Kepala 
Jurnal Law Reform

Volume 12, Nomor 2, Tahun 2016

KPKNL yang wilayah kerjanya meliputi objek Hak Tanggungan.

- Penentuan tanggal pelaksanaan lelang oleh KPKNL.

- Pengumuman lelang oleh Pengadilan Agama.

- Adanya uang jaminan dari peserta lelang yang disetorkan ke bendahara KPKNL.

- Pelaksanaan lelang.

- Pengesahan pembeli.

- Pembayaran harga lelang oleh pemenang lelang.

- Penyerahan dokumen kepemilikan tanah.

- Setelah lelang selesai maka pejabat lelang membuat berita acara lelang yang disebut risalah lelang yang ditanda tangani oleh pejabat lelang, penjual, dan pembeli.

Lelang eksekusi Hak Tanggungan dapat dilaksanakan apabila barang yang dilelang tersebut harus sudah dilepaskan dari kekuasaan termohon dalam hal ini debitor. Hal ini untuk menghindari adanya permasalahan yang mungkin dapat terjadi di kemudian hari dengan pihak ketiga atau pembeli. Hal tersebut juga dimaksudkan sebagai upaya untuk melindungi pihak
Program Studi Magister Ilmu Hukum Fakultas Hukum Universitas Diponegoro

pemenang lelang untuk mendapatkan haknya.

Dalam hal ini yang bertindak selaku penjual lelang adalah Ketua Pengadilan Agama untuk kepentingan kreditor, sehingga yang berhak menentukan syarat-syarat lelang adalah Ketua Pengadilan Agama selaku pemohon lelang. Sebelum pelelangan dilaksanakan harus didahului pengumuman sebayak 2 (dua) kali berturut-turut dengan tenggang waktu 15 hari melalui surat kabar. Sebelum saat pengumuman lelang dikeluarkan debitor masih diberi kesempatan untuk melunasi utang, biaya dan bunga (Pasal 20 ayat (5) UUHT dan Penjelasannya).

Berdasarkan analisa penulis, Pengadilan Agama Semarang dalam melaksanakan eksekusi Hak Tanggungan telah diatur dalam Pasal 224 HIR/258 RBg yaitu kewenangan untuk menetapkan sita eksekusi atas tanah-tanah yang telah dijamin dengan Hak Tanggungan di wilayah hukum dimana debitor tinggal. Selain ketentuan tersebut berdasarkan Pasal 6 UndangUndang Hak Tanggungan menyatakan bahwa apabila debitor cidera janji, pemegang Hak Tanggungan pertama mempunyai hak untuk menjual obyek Hak Tanggungan atas kekuasaan sendiri melalui pelelangan umum 
Jurnal Law Reform

Volume 12, Nomor 2, Tahun 2016

serta mengambil pelunasan piutangnya dari hasil penjualan tersebut. Eksekusi ini cenderung lebih mudah dari pada pertolongan hakim berdasarkan Pasal 224 HIR/258 Rbg karena tidak memerlukan adanya perintah dari Ketua Pengadilan Agama untuk melakukan penjualan obyek Hak Tanggungan melalui pelelangan umum. Kreditor pemegang Hak Tanggungan dapat langsung mengajukan penjualan obyek Hak Tanggungan yang bersangkutan.

2.Eksekusi lelang Hak Tanggungan atas kekuasaan sendiri (Parate Executie) di KPKNL Semarang

Pengertian lelang eksekusi telah disebutkan dalam Pasal 1 ayat (4) Peraturan Menteri Keuangan Nomor 27/PMK.06/2016 yaitu : "Lelang Eksekusi adalah lelang untuk melaksanakan putusan atau penetapan pengadilan, dokumen-dokumen lain yang dipersamakan dengan itu, dan/ atau melaksanakan ketentuan dalam peraturan perundang-undangan", antara lain Lelang Eksekusi Panitia Urusan Piutang Negara (PUPN), Lelang Eksekusi Pengadilan, Lelang Eksekusi Pajak, Lelang Eksekusi Harta Pailit, Lelang Eksekusi Pasal 6 Undang-Undang Hak Tanggungan (UUHT), Lelang Eksekusi dikuasai/tidak dikuasai Bea Cukai, Lelang Eksekusi Barang Sitaan Pasal 45 Kitab
Program Studi Magister Ilmu Hukum Fakultas Hukum Universitas Diponegoro

Undang-Undang Hukum Acara Pidana (KUHP), Lelang Eksekusi Barang Rampasan, Lelang Eksekusi Barang Temuan, Lelang Eksekusi Fidusia, Lelang Eksekusi Gadai.

Dari penelitian yang dilakukan penulis pada KPKNL Semarang diperoleh keterangan tentang proses pelaksanaan lelang eksekusi objek hak tanggungan pada Kantor Pelayanan Kekayaan Negara dan Lelang (KPKNL) Semarang meliputi kegiatan sebelum lelang, pelaksanaan lelang dan kegiatan setelah lelang dengan tahapan yang akan digambarkan dengan sebuah bagan sebagai berikut: 10
${ }^{10}$ Wawancara dengan Pejabat Lelang Bapak Dani dan data diambil dari Kantor Pelayanan Kekayaan Negara dan Lelang Semarang pada tanggal 13 Februari 2017. 


\section{Prosedur Lelang KPKNL Semarang}

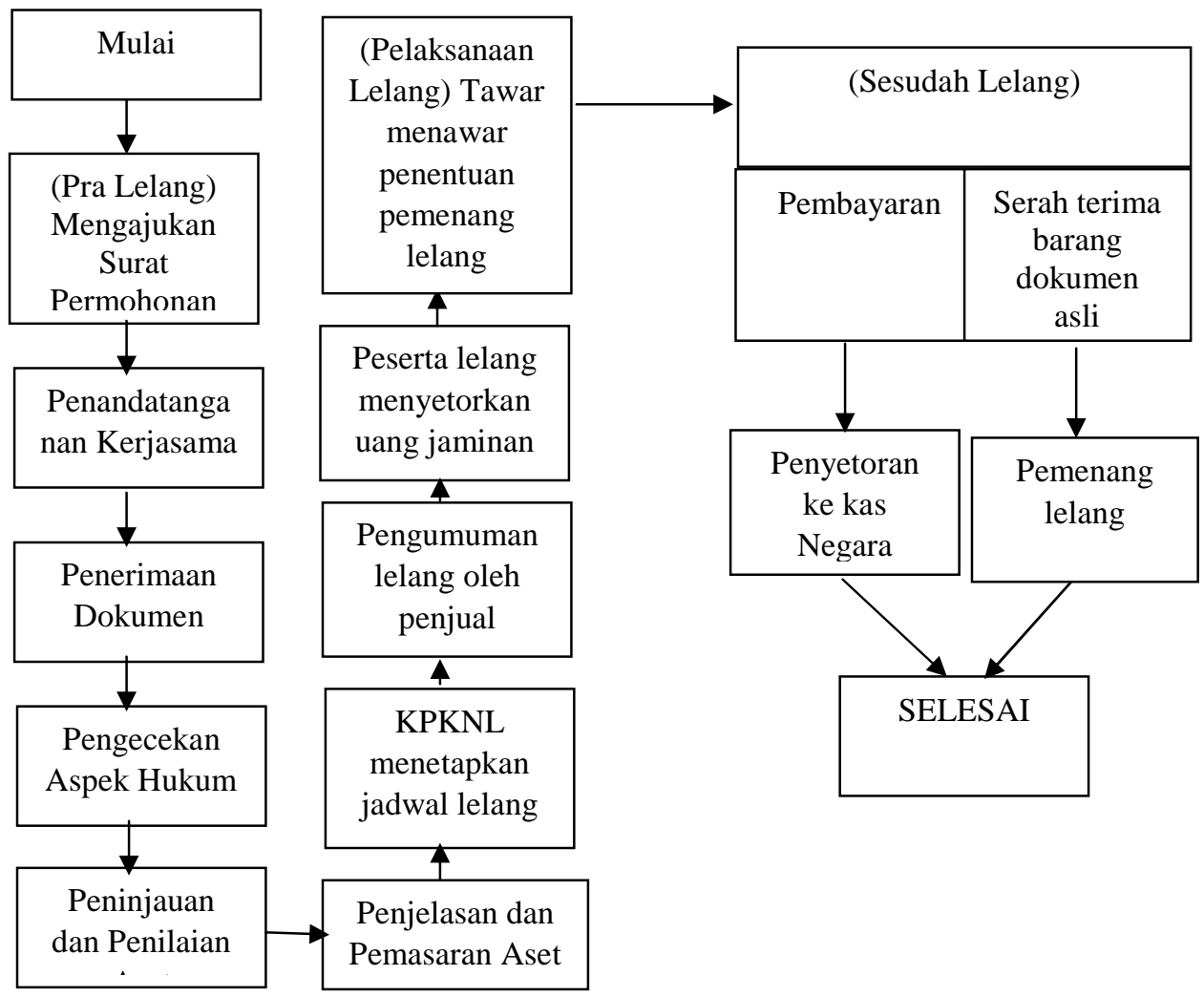

Sumber : Kantor Pelayanan Kekayaan Negara dan Lelang Semarang

Dalam Penjelasan Umum angka 9 UUHT disebutkan bahwa salah satu ciri khas hak tanggungan adalah mudah dan pasti eksekusinya jika debitor cidera janji. Lebih lanjut Penjelasan Umum tersebut menyatakan bahwa eksekusi hak tanggungan dilakukan berdasarkan lembaga parate executie sebagaimana dimaksud dalam Pasal 224 HIR dan 258 Rbg. Penjelasan Pasal 14 ayat (2) dan ayat (3) juga menyatakan bahwa irah-irah yang terdapat pada sertifikat hak tanggungan dimaksudkan untuk menegaskan adanya kekuatan eksekutorial pada sertifikat hak tanggungan, sehingga jika debitor cidera janji maka sertifikat hak tanggungan dieksekusi seperti halnya putusan pengadilan yang telah memperoleh kekuatan hukum tetap, melalui tata cara dan dengan menggunakan lembaga parate executie sesuai hukum acara perdata yang berlaku.

Pada hak tanggungan, menurut Pasal 11 ayat (2) huruf e UUHT juga ditegaskan bahwa dalam Akta Pemberian Hak 
Jurnal Law Reform

Volume 12, Nomor 2, Tahun 2016

Tanggungan (APHT) dicantumkan janji-janji, antara lain janji pemegang hak tanggungan pertama untuk menjual objek hak tanggungan atas kekuasaan sendiri jika debitor cidera janji. Sebagai suatu hak yang diperjanjikan, maka keberadaanya baru ada jika secara tegas disepakati bersama oleh debitor dan kreditor dalam APHT. Suatu janji baru ada dan mengikat jika telah tercapai kesepakatan antara kedua belah pihak yang memperjanjikan.

Apabila APHT tersebut sudah didaftarkan ke Kantor Pertanahan, maka secara otomatis janji-janji yang tercantum di dalamnya (termasuk janji untuk menjual atas kekuasaan sendiri) ikut didaftar sehingga mempunyai kekuatan mengikat bagi para pihak dan pihak ketiga. Sehingga bila debitor wanprestasi maka penjualannya harus dilakukan melalui pelelangan umum. Ketentuan harus dijual di muka umum itu dimaksudkan untuk memberikan perlindungan kepada debitor dari kenakalan kreditor, yakni guna menghindari terjadinya penjualan jaminan yang merugikan debitor.

Dengan demikian jika debitor benarbenar wanprestasi maka pemegang hak tanggungan pertama dapat melaksanakan janji tersebut dengan menjual lelang objek hak tanggungan atas kekuasaan sendiri
Program Studi Magister IImu Hukum Fakultas Hukum Universitas Diponegoro

(parate eksekusi). Pelaksanaan parate eksekusi tidak mendasarkan pada Pasal 224 HIR dan 258 Rbg seperti yang disebutkan oleh Penjelasan Umum angka 9 dan Penjelasan Pasal 14 dan 26 UUHT. Jadi parate eksekusi itu dilaksanakan tanpa fiat eksekusi atau penetapan dari Ketua Pengadilan. Hal ini sesuai dengan hak yang diberikan oleh undang-undang kepada kreditor pertama sebagaimana yang diatur dalam Pasal 6 UUHT.

Sedang eksekusi menurut Pasal 224 HIR dan 258 Rbg bukanlah parate eksekusi, karena eksekusi berdasarkan Pasal tersebut harus meminta fiat eksekusi kepada Ketua Pengadilan. Eksekusi menurut Pasal 224 HIR dan 258 Rbg ditujukan pada grosse akta hipotik dan surat hutang yang mempunyai kekuatan eksekutorial. Jadi eksekusi berdasarkan kedua Pasal tersebut harus meminta fiat eksekusi kepada dan dilaksanakan atau dipimpin oleh Ketua Pengadilan, sedangkan parate eksekusi dilakukan sendiri oleh kreditor tanpa meminta fiat eksekusi kepada Ketua Pengadilan.

Pelaksanaan lelang eksekusi melalui KPKNL merupakan tindak lanjut dari Pasal 6 UUHT, dimana pemegang Hak Tanggungan mempunyai hak untuk menjual obyek Hak Tanggungan atas kekuasaan sendiri melalui 
Jurnal Law Reform

Volume 12, Nomor 2, Tahun 2016

pelelangan umum. Hal ini juga diperkuat adanya Peraturan Menteri Keuangan Nomor 27/PMK.06/2016 tentang Petunjuk Pelaksanaan Lelang dimana terhadap debitor wanprestasi dapat langsung mengajukan permohonan lelang kepada KPKNL. Sedangkan menurut pasal 11 ayat (2) UU No. 4 Tahun 1996, untuk dapat menggunakan wewenang menjual obyek hak tanggungan atas kekuasaan sendiri tanpa persetujuan dari debitor diperlukan janji dari debitor. Dimana janji tersebut dicantumkan dalam APHT. Meskipun Pasal 11 ayat (2) mengatur demikian, kreditor dengan dasar Pasal 6 UUHT tetap dapat melaksanakan wewenang untuk menjual obyek hak tanggungan, dengan kata lain baik dicantumkan atau tidak janji tersebut dalam APHT, pemegang hak tanggungan pertama mempunyai kekuasaan/wewenang untuk dapat melakukan tindakan yang demikian itu. Pencantuman janji hanya akan memberikan rasa mantap kepada pemegang Hak Tanggungan dari pada tidak dicantumkan jaji yang dimaksud dalam APHT.

B. Hambatan dalam pelaksanaan eksekusi Lelang dengan tanpa adanya putusan di Pengadilan Agama Seamarang
Program Studi Magister Ilmu Hukum Fakultas Hukum Universitas Diponegoro

Pada prakteknya eksekusi lelang Hak Tanggungan di Pengadilan Agama Semarang tidak selalu berjalan dengan baik. Adanya hambatan dalam melaksanakn eksekusi Hak Tanggungan yang dihadapi oleh Pengadilan Agama Semarang, diantaranya adalah:

1.Perlawanan pihak tereksekusi

Pihak debitor acapkali memberikan perlawanan terhadap pelaksanaan eksekusi, hal ini disebabkan debitor merasa dirugikan dengan adanya eksekusi tersebut. Perlawanan debitor bisa diajukan sebelum adanya penetapan eksekusi dengan mengajukan perlawanan ke Pengadilan Agama apabila dalam proses eksekusi telah menyalahi peraturan Perundangundangan yang berlaku. Akan tetapi seperti kasus di atas yang telah dikemukakan sebelumnya intimindasi terhadap peserta lelang menjadi salah satu alternative yang di pandang efektif untuk menggagalkan proses lelang.

\section{Perlawanan pihak ketiga}

Kaitanya dengan perlawanan pihak ketiga dalam hal ini yang sering terjadi adalah ketika lelang sudah dilaksanakan, secara tiba-tiba ada pihak ketiga yang mengajukan keberatan yang menyatakan bahwa barang/objek yang akan dilelang 
Jurnal Law Reform

Volume 12, Nomor 2, Tahun 2016

itu adalah miliknya. Permasalah hukum seperti ini yang paling sering dijumpai dalam prakteknya. ${ }^{11}$

Seharusnya terhadap pihak ketiga yang merasa keberatan dengan pelaksanaan eksekusi tersebut dapat mengajukan gugatan perlawanan pihak ketiga (denden verzet) secara resmi melalui surat perlawanan yang didaftarkan kepada Pengadilan Agama yang bersangkutan dengan melampirkan bukti kepemilikan atas objek yang dilelang.

Pada dasarnya pihak ketiga dapat mengajukan perlawanan terhadap eksekusi suatu putusan. Berdasarkan ketentuan Pasal 195 ayat (6) HIR / Pasal 206 Rbg ayat (6), maka satu-satunya syarat agar dapat diterima pihak orang lain (pihak ketiga) untuk mengajukan perlawanan tersebut adalah bahwa barang yang akan dieksekusi adalah miliknya. Oleh karena itu, bila alasan pengajuan perlawanan adalah di luar hak milik, misalnya hak sewa, hak pakai, dan sebagainya tidak diperkenankan mengajukan perlawanan tersebut. Perlawanan pihak ketiga adalah upaya
Program Studi Magister Ilmu Hukum Fakultas Hukum Universitas Diponegoro

hukum luar biasa dan oleh karenanya pada azasnya tidak menangguhkan eksekusi.

Yahya harahap12 menjelaskan bahwa salah satu syarat agar perlawanan dapat dipertimbangkan sebagai alasan untuk menunda eksekusi, harus diajukan sebelum eksekusi dijalankan/dilaksanakan. Kalau eksekusi sudah dijalankan, tidak ada relevansinya untuk menunda eksekusi. Senada dengan Putusan MA tanggal 31 Agustus 1977 No. 697 K/Sip/1974, ditegaskan tentang formalitas pengajuan perlawanan terhadap eksekusi harus diajukan sebelum penjualan lelang dijalankan (sebelum eksekusi dijalankan). Kalau eksekusi sudah dijalankan, upaya yang dapat diajukan pihak ketiga untuk membatalkan eksekusi harus melalui gugatan. Begitu juga dalam Putusan MA No. 786 K/Pdt/1988 antara lain ditegaskan :

- derden verzet atas eksekusi berdasarkan alasan sebagai pemilik dapat dibenarkan asal diajukan sebelum eksekusi selesai;
11 Wawancara dengan Yayuk, S.H. sebagai Seksi Hukum dan Informasi, Pejabat Lelang dan Lawyer di KPKNL Semarang pukul 11.00 WIB tanggal 14 Februari 2017.
12 M. Yahya Harahap, Ruang Lingkup Permasalahan Eksekusi Bidang Perdata, (Jakarta: PT. Gramedia. 2008), hIm. 27 
- sehubungan dengan itu, oleh karena perlawanan diajukan pada saat sita eksekusi diajukan, Pengadilan Negeri diperintahkan untuk mengankat sita eksekusi.

Debitor/tereksekuai dapat mengajukan gugatan terhadap eksekusi dengan formalitas : 13

- Pihak tereksekusi adalah pihak ketiga;

- Pihak ketiga tersebut adalah pemilik dari objek eksekusi, baik itu pemegang hak milik, hak guna usaha, hak guna bangunan, hak pakai, termasuk penanggung Hak Tanggungan dan hak sewa;

- Pengajuan gugatan dilakukan setelah eksekusi sudah selesai dijalankan;

Debitor/tereksekuai dapat mengajukan perlawanan terhadap eksekusi dengan formalitas : 14

- Perlawanan harus diajukan sebelum penjualan lelang dijalankan (sebelum eksekusi);

- Alasan perlawanan adalah untuk menunda eksekusi;

- Pihak-pihak yang dapat melakukan perlawanan adalah :

${ }^{13}$ Ibid.

14 Ibid.hlm. 28.
- Pihak ketiga yang akan dieksekusi yang mengaku sebagai miliknya (pemegang hak milik, HGU, HGB, Hak Pakai, termasuk penanggungan Hak Tanggungan, dan hak sewa;

- Penyewa yang objeknya bukan tanah; atau

- Tereksekusi sendiri apabila dia sudah melaksanakan putusan itu dengan suka rela atau dalam hal cara-cara melakukan penyitaan tersebut dilakukan yidak sesuai dengan hukum yang berlaku.

- Objek perlawanan dapat berupa :

- Putusan verstek bagi tergugat yang tidak hadir;

- Sita Eksekusi bagi tergugat;

- Sita conservatoir, sita revindicatoir, dan sita eksekusi bagi pihak ketiga;

- Waktu pengajuan perlawanan adalah sebelum penjualan lelang dijalankan (sebelum eksekusi dijalankan).

Dengan demikian dapat penulis simpulkan, tereksekusi dalam hal ini pelawan dapat melakukan ataupun mengajukan gugatan perdata atau perlawanan terhadap lelang eksekusi dengan terlebih dahulu memenuhi 
Jurnal Law Reform

Volume 12, Nomor 2, Tahun 2016

formalitas yang telah diuraikan pada pertimbangan sebelumnya.

\section{Simpulan Saran}

A. Simpulan

Cakupan eksekusi lelang pada sengketa ekonomi syariah dengan tanpa adanya Putusan Pengadilan dapat melalui parate eksekusi atau eksekusi berdasarkan title eksekutorial.

1. Parate eksekusi dilakukan sendiri oleh kreditor tanpa meminta fiat eksekusi kepada Ketua Pengadilan yaitu melalui pelelangan umum serta mengambil pelunasan piutangnya dari hasil penjualan tersebut. Eksekusi ini lebih mudah dari pada pertolongan hakim karena tidak memerlukan adanya perintah dari Ketua Pengadilan Agama.

2. Eksekusi berdasarkan title eksekutorial ini titik fokusnya ada dalam tangan Ketua Pengadilan sebagaimana diatur dalam Pasal 224 HIR/258 RBg yaitu kewenangan untuk menetapkan sita eksekusi atas tanah-tanah yang dijamin dengan Hak Tanggungan di wilayah hukum dimana debitor tinggal. Pada faktanya eksekusi ini lebih banyak diajukan oleh kreditur karena apabila terhadap objek lelang yang terjual tersebut terdapat pihakpihak yang tidak mau menyerahkan objek lelang kepada pemenang lelang, maka
Program Studi Magister Ilmu Hukum Fakultas Hukum Universitas Diponegoro

Pengadilan berdasarkan ketentuan Pasal 14 UUHT memiliki kewenangan untuk melaksanakan eksekusi pengosongan terhadap objek lelang tersebut.

Hambatan yang dialami Pengadilan Agama Semarang dalam Pelaksanaan Eksekusi Lelang dengan Tanpa Adanya Putusan adalah:

1. Perlawanan pihak tereksekusi, pihak debitor acapkali memberikan perlawanan terhadap pelaksanaan eksekusi, hal ini disebabkan debitor merasa dirugikan dengan adanya eksekusi tersebut. Perlawanan debitor bisa diajukan sebelum eksekusi dijalankan. Kalau eksekusi sudah dijalankan, upaya yang dapat diajukan pihak tereksekusi untuk membatalkan eksekusi harus melalui gugatan. Akan tetapi debitor memilih memakai jalan pintas sebagaimana kasus yang telah dikemukakan dalam penelitian ini sebelumnya. Intimindasi terhadap peserta lelang menjadi alternative yang di pandang efektif untuk menggagalkan proses lelang.

2. Perlawanan pihak ketiga, Kaitanya dengan perlawanan pihak ketiga dalam hal ini yang sering terjadi adalah ketika lelang sudah dilaksanakan, secara tiba-tiba ada pihak ketiga yang mengajukan keberatan yang menyatakan bahwa barang/objek yang akan dilelang itu adalah miliknya. Permasalah 
hukum seperti ini yang paling sering Amiruddin dan Zainal Asikin. 2012. Pengantar dijumpai dalam prakteknya.

Metode Penelitian Hukum. Jakarta: PT.

B. Saran RajaGrafindoPersada.

1. Diperlukan peraturan perundang-undangan yang mengatur tentang sanksi terhadap piahak-pihak yang berupaya menghambat proses hukum acara di Lembaga Peradilan.

2. Perlunya ada ketegasan dari Ketua Pengadilan Agama Semarang dalam menegakkan hukum agar tercipta supremasi hukum.

Affandi, Ateng, Wahyu Affandi, 1998. Tentang melaksanakan Putusan Hakim Perdata, Bandung: Alumni.

Afzalurrahman, 1995. Doktrin Ekonomi Islam, Jogjakarta: Dhana Bakti Wakaf.

Antonio, Muhammad Syafi'i, 2001. Bank Syariah, Dari Teori ke Praktek, Cet-1, Jakarta: Gema Insani Press.

3. Pelaksanaan eksekusi lelang Hak Ansori, Abdul Ghofur., 2010, Penyelesaian Tanggungan demi kelancaran prosesnya dapat juga memilih alternative lelang secara online, hal ini dapat meminimalisir perbuatan intimindasi dari pihak debitor maupun kuasa hukumnya karena tidak dapat beertemu secara langsung dengan peserta lelang.

Sengketa Perbankan Syariah (Analisis Konsep dan UU No. 21 Tahun 2008), Yogyakarta: Gajah Mada University Press.

Ali, M Daud, 1998. Hukum Islam. Jakarta: PT Raja Grafindo Persada.

Al-assal, Ahmad Muhammad dan Fathi Ahmad Abdul Karim, 1980. Sistem Ekonomi Islam, Prinsip-Prinsip dan Tujuan-Tujuanya,

\section{Daftar Pustaka}

\section{BUKU}

Surabaya: PT. Bina IImu.

Khakim, Abdul, 2003, Pengantar Hukum Ketenagakerjaan Indonesia berdasarkan Undang-Undang Nomor 13 Tahun 2003, Bandung: Citra Aditya Bakti.

Rajagukguk, HP., 2000, Makalah Peran Serta Pekerja dalam Pengelolaan Perusahaan (Codetermination).

Al Fanjani, Muhammad Syauqi, 1989. Ekonomi Islam Masa Kini. Bandung : Husaini.

Arto, A. Mukti, 2000. Praktek Perkara Perdata. Yogyakarta: Pustaka Pelajar.

Bisri, Cik Hasan., 2000, Peradilan Agama di Indonesia, Jakarta: PT. Raja Grafindo Persada.

Budiardjo, Miriam., 1998, Dasar-Dasar IImu Politik, Jakarta: Gramedia Pustaka Utama. 
Jurnal Law Reform

Volume 12, Nomor 2, Tahun 2016
Program Studi Magister Ilmu Hukum Fakultas Hukum Universitas Diponegoro
Chapra, M. Umar., 2001, Masa Depan ekonomi, Sebuah Tinjauan Islam, Jakarta: Gema Insani Press.

Dewi, Gamala, 2004. Aspek-Aspek Hukum Dalam Perbankan dan Perasuransian Syariah di Indonesia, Jakarta: Kencana.

Harahap, M. Yahya., 2008, Ruang Lingkup Permasalahan Eksekusi Bidang Perdata, Jakarta: PT. Gramedia.

Huda, Nurul dkk., 2008, Ekonomi Makro Islam, Pendekatan Teoritis, Cet. 2, Jakarta: Prenada Media Group.

Indroharto., 1994, Asas-Asas Umum Pemerintahan yang Baik, dalam Paulus Efendie Lotulung, Himpunan Makalah Asas-Asas Umum Pemerintahan yang Baik, Bandung: Citra Aditya Bakti.

Kantaprawira, Rusadi., 1998, Hukum dan Kekuasaan, Makalah, Yogyakarta: Universitas Islam Indonesia.

Ka'bah, Rifyal, Penyelesaian Sengketa Ekonomi Syariah Sebagai Sebuah Kewenangan Baru Peradilan Agama, Varia Peradilan, no. 245, Jakarta, April 2006.

Kansil, CST. 1986. Pengantar IImu Hukum dan Tata Hukum Indonesia. Jakarta : Balai Pustaka.

Karim, Adimarwan Azwar, 2006. Sejarah Pemikiran Ekonomi Islam, Jakarta: Rajawali Press.
Marzuki, Peter Mahmud., 2005, Penelitian Hukum, Jakarta: Kencana.

Manan, Muhammad Abdul., 1986, Islamic Economics, Theory and Practice, Cambridge: Houder and Stoughton Ltd.

--------2008. Penerapan Hukum Acara Perdata di Lingkungan Peradilan Agama, Jakarta: Prenada Media.

Martokusumo, Sudikno, 1999. Mengenal Hukum Suatu Pengantar, Yogyakarta : Liberty. -1998. Hukum Acara Perdata Indonesia, Yogyakarta: Liberty.

Mahkamah Agung RI. 1995. Pustaka Peradilan. Jilid VIII, Jakarta : Proyek Pembinaan Teknis Yustisial Mahkamah Agung RI.

Mujahidin, Ahmad, 2012. Pembaharuan Hukum Acara Peradilan Agama, Bogor: Ghalia Indonesia.

Mulyosudarmo, Suwoto., 1990, Kekuasaan dan Tanggung Jawab Presiden Republik Indonesia, Suatu Penelitian Segi-Segi Teoritik dan Yuridis Pertanggungjawaban Kekuasaan, Surabaya: Universitas Airlangga. ND, Mukti Fajar dan Yulianto Achmad. 2010. Dualisme Penelitian Hukum Normatif dan Empiris. Yogyakarta: Pustaka Pelajar.

Rasyid, Raihan A. 1991. Hukum Acara Peradilan Agama, Jakarta: CV. Rajawali. 
Jurnal Law Reform

Volume 12, Nomor 2, Tahun 2016

Satiardja, A. Gunawan., 1990, Dialektika Hukum dan Moral dalam Pembangunan Masyarakat Indonesia, Yogyakarta: Kanisius.

Santoso, Listyio Budi. 2009. Kewenangan Peradilan Agama Dalam Menyelesaikan Sengketa Ekonomi Syari'ah. Semarang : Pusataka Undip.

Soedawi, Sri, 1980. Hukum Jaminan di Indonesia. Pokok-pokok Hukum Jaminan dan Jaminan Perorangan, Yogyakarta: Liberty.

Soemitro, Ronny Haditijo., 2005, Metodologi Penelitian Hukum, Jakarta: Ghalia Indonesia.

Soehartono, Irawan., 1999, Metode Penelitian Sosial - Suatu Tehnik Penelitian Bidang Kesejahteraan Sosial Lainnya, Bandung: Remaja Rosda Karya.

Soekanto, Soerjono., 2007. Pengantar Penelitian Hukum. Jakarta: UI-Press.

2004. Faktor-Faktor Yang Mempengaruhi Penegakan Hukum Cetakan Kelima. Jakarta : Raja Grafindo Persada. dan Sri Mamudji. 2001. Penelitian Hukum Normatif. Jakarta: PT. Raja Grafindo Persada Mukti Fajar dan Yulianto Achmad. 2010. Dualisme Penelitian Hukum Normatif \& Empiris. Yogyakarta: Pustaka Pelajar.

Sunggono, Bambang., 2005, Metodologi Penelitian Hukum, Jakarta: PT Raja Grafindo.

Subekti., 1982, Hukum Acara Perdata Indonesia, Jakarta: Bina Cipta.
Program Studi Magister Ilmu Hukum Fakultas Hukum Universitas Diponegoro
1987. Hukum Acara Perdata di Indonesia. Jakarta: Pradnza Paramita.

-1978. Kamus Hukum, Jakarta: Pradnya Paramita.

-1997. Hukum Acara Perdata. Jakarta: BPHN.

Suma, Muhammad Amin, 2006. Seputar Ekonomi Syariah Studi Tentang Prinsip-Prinsip Ekonomi Syariah di Indonesia, Jakarta: Mahkamah Agung.

Suyuthi, Wildan, 2004. Sita Eksekusi Praktek Kejurusitaan Pengadilan, Jakarta: Tatanusa.

Susanti, Retno Wulan dan Iskandar Oerip kartawinata, 1979. Hukum Acara Perdata dalam Teori dan Praktik . Bandung: Alumni.

Sya'labi, Ahmad, 1994. Sejarah dan kebudayaan Islam, Jakarta: Pustaka Al-Husna.

Tim Penulis P3EI UII Jogyakarta, 2008. Ekonomi Islam, Jakarta: Raja Grafindo Persada.

Yatim, Badri, 1994. Sejarah Peradaban Islam, Jakarta: Raja Grafindo Persada.

Warasih, Esmi., 2005, Pranata Hukum, Sebuah Telaah Sosiologis, Semarang: PT. Suryandaru Utama.

Zaman, Hasanuz., 1984, Ekonomic Function of on Islamic State, Licester: The Islamic Foundation.

\section{PERATURAN PERUNDANG-UNDANGAN}

Undang-Undang Dasar 1945. 
Jurnal Law Reform

Volume 12, Nomor 2, Tahun 2016

Undang-Undang No. 7 Tahun 1989 tentang

Peradilan Agama.

Undang-Undang No. 4 Tahun 1996 tentang Hak Tanggungan.

Undang-undang No. 4 Tahun 2004 tentang Kekuasaan Kehakiman.

Undang-Undang No. 3 Tahun 2006 tentang Peradilan Agama.

Undang-Undang No. 21 Tahun 2008 tentang Perbankan Syariah.

Undang-Undang No. 48 Tahun 2009 tentang Kekuasaan Kehakiman.

Peraturan Mahkamah agung No. 14 Tahun 2016 tentang Tata Cara Penyelesaian Perkara Ekonomi Syariah. 